\title{
ВПЛИВ ЦУКРОВОГО ДІАБЕТУ НА РЕЗУЛЬТАТИВНІСТЬ ХІРУРГІЧНОГО ЛІКУВАННЯ ГЕНІТАЛЬНОГО ПРОЛАПСУ*
}

\author{
Сафонов Р. А., ${ }^{1,2}$ Лазуренко В. В. ${ }^{1}$, Пасіешвілі Н. М. ${ }^{3}$, \\ Карпенко В. Г. ${ }^{4}$, Садчикова М. В. ${ }^{5}$ \\ ${ }^{1}$ Харківський національний медичний університет, м. Харків, Украӥна; \\ ${ }^{2}$ Харківський регіональний перинатальний центр, л. Харків, Украйна; \\ ${ }^{3}$ Харківський обласний клінічний перинатальний центр, м. Харків, Украйна; \\ ${ }^{4}$ Харківський національний університет іл. В. Н. Каразіна, м. Харків, Україна; \\ ${ }_{5}^{5}$ Харківська медична акаделія післядипломної освіти, м. Харків, Украӥна \\ urology.edu.ua@gmail.com
}

Цукровий діабет (ЦД) - одне з найпоширеніших захворювань у всьому світі, але на теперішній час спостерігається тенденція до щорічного збільшення кількості хворих. За даними American Diabetes Association у всьому світі більше ніж 366 млн. осіб хвоpie на ЦД (або 1 з 11 дорослих), а до 2030 р. очікуеться зростання до 425 млн [1]. Хвороба посідае трете місце в структурі смертності та призводить до розвитку тяжких ускладнень з боку серцево-судинної, нервової, сечостатевої та інших систем людини. Тому, за даними ВООЗ, ЦД віднесено до пріоритетних неінфекційних захворювань [2].

ЦД може виникнути в будь-якому віці, однак його другий тип (ЦД2) виникае частіше у осіб старше 45 років. Ризик розвитку ЦД збільшуеться у людини з надмірною масою тіла та ожирінням, гіпертоніею, високим рівнем тригліцеридів або низьким холестерину, з підвищеним рівнем глюкози в крові, генетичною схильністю до розвитку ЦД, з пасивним способом життя, тощо [2]. Метаболічні та ендокринні порушення, які виникають на тлі ЦД, впливають на стан здоров'я жінок, підвищують ризик ускладнень після гінекологічних операцій, зокрема з приводу генітального пролапсу.

Генітальний пролапс (ГП) - зміщення або випадіння статевих органів, яке вражає мільйони жінок в світі, особливо похилого віку. Частота ГП сягае 45-50\% жіночого населення, а у кожної третьої хворої потребуе хірургічного лікування.

Необхідно відзначити, що ГП суттево знижуе якість життя жінки, а покращити

* Робота виконана у межах комплексної науково-дослідної роботи кафедри акушерства і гінекології № 2 Харківського національного медичного університету «Розробка нових підходів до діагностики, лікування та профілактики ускладнень у вагітних та при захворюваннях репродуктивної системи» (№ державної реєстрації 0114U004147).

Установою, що фінансуе дослідження, е МОЗ України.

Автори гарантують повну відповідальність за все, що опубліковано в статті.

Автори гарантують відсутність конфлікту інтересів і власної фінансової зацікавленості при виконанні роботи та написанні статті.

Рукопис надійшов до редакції 16.03.2021. 
його може переважно тільки хірургічне лікування [3].

До фракторів ризику розвитку ГП належать тяжка фізична праця, травматичні пологи в анамнезі, недостатність естрогенів у періменопаузальному віці та інші [4]. Також важливе значення має екстрагенітальна патологія, зокрема цукровий діабет (ЦД), який суттево порушує трофріку тканин, зокрема статевих шляхів. Також причинами вважають дегенерацію сполучної тканини та недостатність колагену, що виникають через зміни вмісту статевих гормонів. Тому оцінка гормонального статусу жінок з ГП на тлі ЦД може бути важливим прогностичнім фрактором. Хірургічне лікування ГП у хворих на ЦД часто закінчується рецидивом пролапсу геніталій через неспроможність тканин, уражених ЦД, зростатися та відновлюватися [5, 6]. Тому пошук оптимальних підходів до лікування ГП у жінок з ЦД є актуальним завданням сучасної гінекології.

Мета дослідження - оптимізація хірургічного лікування ГП у жінок з ЦД та визначення впливу ЦД на результативність хірургічного лікування ГП шляхом порівняння різноманітних сучасних підходів до терапії ГП.

\section{МАТЕРІАЛИ ТА МЕТОДИ}

Дослідження проведено на клінічній базі кафедри акушерства та гінекології №2 Харківського національного медичного університету в гінекологічному відділені Обласної клінічної лікарні. Обстежено 52 жінки менопаузального віку з генітальним пролапсом 3-4 ступеня за класифікацією Baden-Wolker (1972), з них у 30 хворих крім генітального пролапсу діагностували ЦД2 (основна група), у 22 жінки був тільки ГП (група порівняння). Контрольну групу склали 20 жінок менопаузального віку без ознак ГП та ЦД.

В залежності від методу лікування обстежені жінки були розподілені на три групи. До першої групу включено 18 хворих (9 жінок основної групи та $9-3$ групи порівняння), яким була виконана піхвова екстирпація матки, передня кольпорафія, кольпоперінеорафрія. До другої клінічної групи увійшли 20 хворих (по 10 хворих з основної групи і групи порівняння), яким виконана піхвова екстирпація матки 3 однобічною сакроспінальною фіксацією купола піхви. У третю групу залучено 14 жінок (по 7 жінок з основної групи і групи порівняння), яким після піхвової екстирпації виконана кольпопексія за допомогою по- ліпропіленової сітки «Полімеш» («Фиатос», Білорусь), до складу якої входить поліглікапролактон. Крім загального клініколабораторного обстеження, проводилася консультація уролога для визначення ступеня нетримання сечі, ендокринолога для визначення ступеня тяжкості ЦД та переведення хворої на інсулінотерапію на час періопераційного періоду. Для визначення гормональних змін в організмі жінок з ЦД та ГП визначали вміст ЛГ, ФСГ, пролактину, естрадіолу, кортизолу, тестостерону, гормонів щитоподібної залози (Т3, Т4, ТТГ), ліпідний профіль, за допомогою імуноферментного аналізу з використанням стандартних наборів. Для визначення стану промежини та суміжних тазових органів виконували ультразвукове дослідження (УЗД), зокрема трансвагінальну ехографію та доплерометрію судин органів малого тазу та промежини з використанням апарату Philips HD 11XE. Також проводили леваторний тест, Q-tip тест, тест Bonney, урофлоуметрію. Статистична обробка отриманих даних проведена за допомогою методів параметричної статистики з застосуванням програм «Statistica 6.0» i «Biostat».

\section{РЕЗУЛЬТАТИ ТА ЇХ ОБГОВОРЕННЯ}

Середній вік жінок в основній групі склав $-66,4 \pm 7,3$ років, в групі порівняння $-65,6 \pm 4,9$ років, в контрольній $63,2 \pm 5,8$ років. Обстежені хворі пред’яв- ляли скарги на часте сечовипускання, нетримання сечі, особливо під час кашлю, сміху, напрузі, сексуальні проблеми (зниження чутливості, болісні відчуття під час 
статевого акту або його неможливість). Жінки основної групи додатково мали особливі скарги на постійну спрагу, підвищену втомлюваність, часте почуття голоду, підвищений апетит, недостатність енергії, оніміння в руках та ногах, часті інфекційні ураження шкіри та піхви, тривале загоєння ран, рецидиви інфекційних захворювань статевих шляхів (кольпіти). Рівень глюкози в крові натщесерце у жінок основної групи коливався від 6,7 до 11,5 моль/л, гліколізований гемоглобін (HbA1c) дорівнював 6,5-9,0 \%, порушення толерантності до глюкози - 7,9-11 ммоль/л. Вміст загального холестерину 5,8 \pm 1,3 ммоль/л, ЛПНП $2,9 \pm 0,3$ ммоль/л, ЛПВП - 0,9 \pm 0,2 ммоль/л, тригліцериди - 2,1 \pm 0,2 ммоль/л. В якості терапії вони отримували глюкозознижуючі препарати у дозуваннях, призначених ендокринологом.

Менопауза призводить до різних змін в організмі жінки, які можуть впливати на перебіг ЦД. Гормональні зміни впливають на реакцію клітин на інсулін, а рівень глюкози може бути менш прогнозованим, його треба частіше контролювати. Більш низькі рівні естрогенів у менопаузальному періоді можуть призвести до підвищення ризику розвитку захворювань сечостатевої системи у жінок з ЦД, особливо при ГП [7]. Також під час менопаузи спостерігається підвищення маси тіла [5], середня маса у жінок основної групи склала 91,3 \pm 9,6 кг, групи порівняння - 82,4 \pm 7,9 кг, контрольної $74,5 \pm 6,2$ кг. Результати обстеження гормонального стану у досліджених хворих похилого віку представлено в таблиці 1.

Дослідження вмісту гормонів в основній групі продемонструвало, що рівень ЛГ складав $58,3 \pm 4,8 \mathrm{MO} /$, що було в 5 разів вище за норму (контроль 10,5 \pm 1,2 МО/л), ФСГ у 2 раза вище за контрольні показники $18,6 \pm 2,4 \mathrm{MO} / л$ (контроль - 8,2 $\pm 1,1 \mathrm{MO} / л)$, співвідношення ЛГ/ФСГ у 2,6 раза вище $3,1 \pm 0,2$ (контроль $1,2 \pm 0,1$ ). Пролактин був знижений в 1,65 рази і дорівнював $169,7 \pm 11,9$ мМО/л при контрольних значеннях $246,8 \pm 16,2$ мМО/л. Також у 2,5 рази був знижений естрадіол до 157,3 \pm 9,1 пмоль/л (контроль $396,8 \pm 23,2$ пмоль/л), у 3,2 рази знижений прогестерон 0,41 \pm 0,06 нмоль/л (контроль 1,32 \pm 0,05 нмоль/л). Знижений у 3,4 рази рівень тестостерону - 0,57 \pm 0,11 нмоль/л (контроль 1,92 \pm 0,15 нмоль/л). Діагностовано зниження вдвічі кортизолу до $196,7 \pm 13,5$ нмоль/л у порівнянні з контролем - 432,9 $\pm 26,3$ нмоль/л.

Отримані результати гормонального балансу вказують на вплив менопаузи на зміни рівня гормонів у жінок похилого віку з ЦД. Гормони щитоподібної залози також змінюються у жінок похилого віку 3 ЦД: зростання вдвічі рівня ТТГ $1,12 \pm$ 0,09 мМО/л при контрольних значеннях

Показники гормонального стану в обстежених жінок похилого віку

\begin{tabular}{c|c|c|c}
\hline Гормон & $\begin{array}{c}\text { Хворі на ЦД та ГП } \\
(\mathbf{n}=\mathbf{3 0 )}\end{array}$ & $\begin{array}{c}\text { Хворі на ГП } \\
(\mathbf{n}=\mathbf{2 2})\end{array}$ & $\begin{array}{c}\text { Контрольна група } \\
\text { (n = 20) }\end{array}$ \\
\hline ФСГ (МО/л) & $18,6 \pm 2,4^{*}$ & $14,3 \pm 1,9$ & $8,2 \pm 1,1$ \\
\hline ЛГ (МО/л) & $58,3 \pm 4,8^{*}$ & $37,8 \pm 3,5^{*}$ & $10,5 \pm 1,2$ \\
\hline Пролактин (мМО/л) & $169,7 \pm 11,9^{*}$ & $195,6 \pm 13,4$ & $246,8 \pm 16,2$ \\
\hline Естрадіол (пмоль/л) & $157,3 \pm 9,1^{*}$ & $212,5 \pm 11,3^{*}$ & $396,8 \pm 23,2$ \\
\hline Прогестерон (нмоль/л) & $0,41 \pm 0,06^{*}$ & $0,72 \pm 0,09^{*}$ & $1,32 \pm 0,05$ \\
\hline Тестостерон (нмоль/л) & $0,57 \pm 0,11^{*}$ & $1,08 \pm 0,13^{*}$ & $1,92 \pm 0,15$ \\
\hline Кортизол (нмоль/л) & $196,7 \pm 13,5^{*}$ & $274,3 \pm 18,2^{*}$ & $432,9 \pm 26,3$ \\
\hline Т3 (нмоль/л) & $1,85 \pm 0,03$ & $1,94 \pm 0,09$ & $1,92 \pm 0,11$ \\
\hline Т4 (нмоль/л) & $91,2 \pm 2,7$ & $86,7 \pm 2,4$ & $84,6 \pm 3,1$ \\
\hline ТТГ (мМО/л) & $1,12 \pm 0,09^{*}$ & $0,73 \pm 0,06$ & $0,51 \pm 0,08$ \\
\hline
\end{tabular}

Примітка.

* $\mathrm{P}<0,05-$ порівняння 3 контрольною групою. 
$0,51 \pm 0,08 \mathrm{mMO/л.} \mathrm{Рівень} \mathrm{трийодтироніну}$ (Т3) $-1,85 \pm 0,03$ нмоль/л та тироксину (T4) $91,2 \pm 2,7$ нмоль/л майже не відрізнялися від контрольних параметрів 1,92 \pm 0,11 нмоль/л та 84,6 $\pm 3,1$ нмоль/л відповідно. Отримані результати співпадають 3 даними інших дослідників $[7,8]$

Таким чином, гормональні зміни у жінок похилого віку з ЦД можуть сприяти, разом з іншими факторами, розвитку ГП, a їх своєчасна діагностика та корекція покращити перебіг післяопераційного періоду та якість життя хворих.

Хірургічне лікування жінок з ГП включало трансвагінальну екстирпацію матки без додатків, передню кольпорафію, кольпоперинеорафію з леваторопластикою (вагінальна пластика) у 18 хворих (34,6 \%). Вказане оперативне втручання доповнено сакроспінальною кольпопексіею ліворуч у 20 (38,5 \%) хворих. У 14 (26,9 \%) жінок операція доповнена встановленням поліпропіленової сітки, до складу якої входить поліглікапролактон розміром $2 \times 30$ см. Трансабдомінальний та лапароскопічний доступ при оперативному лікуванні ГП не використовували через тривалість оперативного втручання та можливість виникнення ряду ускладнень у жінок з тяжкою екстрагенітальною патологією, зокрема цукровим діабетом (розходження швів на післяопераційній рані, нагноєння рани, довге загоєння) $[6,8,9]$.

Результати хірургічного лікування жінок основної групи та групи порівняння продемонстрували наступні ускладнення та рецидиви. В результаті проведеного лікування в основній групі виявилося 7 рецидивів $(23,3$ \%) протягом одного року після оперативного втручання, з них після вагінальної пластики - 4 випадки $(44,4 \%)$, після сакроспінальної кольпопексії - 1 (10 \%), після встановлення поліпропіленової сітки, до складу якої входить поліглікапролактон -2 (28,6 \%). У групі порівняння відмічалося 5 рецидивів $(22,7 \%)$, 3 яких 3 (33,3 \%) випадки після вагінальної пластики та по одному після сакроспінальної кольпопексії (10 \%) та встановлення поліпропіленової сітки, до складу якої входить поліглікапролактон (14,3%). Згідно даним сучасної літератури рецидив ГП після гістеректомії та вагінальної пластики спостерігаеться у жінок похилого віку в 25-30 \% паціенток, а після використання синтетичних протезів лише в $9-12 \%[10,11,12]$.

Таким чином, найчастіше рецидиви у жінок з ЦД виникали після вагінальної пластики (44,4 \%), що було достовірно частіше ніж у жінок без ЦД (33,3 \%). Після сакроспінальної кольпопексії частота рецидивів була однаковою (по 10 \%) та найнижчою серед інших методів хірургічного лікування. Використання поліпропіленової сітки, до складу якої входить поліглікапролактон, призвело до ускладнень у 23,3 \% хворих на ЦД та у $22,7 \%$ - без екстрагенітальної патології. Отримані дані вказують на високу ефективність сакроспінальної кольпопексії при лікуванні ГП у жінок з ЦД, особливо однобічний оперативний підхід.

Необхідно відзначити, що однобічна сакропексія дозволяе скоротити час операції за рахунок однобічної, а не двобічної фіксації, що не знижуе ефективність оперативного втручання. Використання синтетичної сітчастої тканини дало майже однакову кількість рецидивів у жінок основної групи та групи порівняння, але жінки з ЦД частіше відмічали алергічну або запальну реакцію на введення поліпропіленової сітки, до складу якої входить поліглікапролактон (відторгнення сітчастого протезу - 14,3\%), а також больовий синдром (42,9\%).

Атрофічні зміни у піхві жінок менопаузального віку зумовлені недостатністю статевих гормонів. Цей стан може бути обтяжений екстрагенітальними захворюваннями, зокрема цукровим діабетом, та негативно впливати на перебіг післяопераційного періоду. Всім хворим, якім планували оперативне лікування з приводу ГП, призначали внутрішньопіхвовий крем з естріолом $(1 \mathrm{мг/ \Gamma )} \mathrm{щоденно} \mathrm{або} \mathrm{супозиторії} \mathrm{з} \mathrm{естріолом}$ $(0,5$ мг) двічі на день за місяць до планової операції та на протязі 30 діб після операції, після чого був проведений аналіз гормонального стану в порівнянні з початковими показниками. Відомо, що естріол впливае на атрофічни зміни піхви, сечовивідного каналу, компенсуе дефіцит естрогенів у жінок в період менопаузи, зменшуе виразність 
атрофічних змін сечостатевих шляхів, атрофічний вульвовагініт, диспареунію, нетримання сечі, сприяе зменшенню загального холестерину [13, 14]. Отримані результати гормонального обстеження прооперованих жінок показали наступні зміни: вірогідне зниження ФСГ $(12,3 \pm 0,4$ МО/л), підвищення естрадіолу (296,5 \pm 13,7 пмоль/л), що вказувало на значний вплив використання естрогенних препаратів на гормональний стан жіночого організму, що було підтверджено і покращенням самопочуття та якості життя хворих.

Таким чином, хірургічне лікування ГП, зокрема сакроспінальна кольпопексія, як доповнення до трансвагінальної екстирпа- ції матки або пластичної піхвової операції зменшує кількість рецидивів та надає можливість зберегти архітектоніку тазового дна та тазових органів, якщо виконуеться без видалення матки $[15,16]$. Ї̈̈ можна рекомендувати як операцію вибору жінкам менопаузального віку з цукровим діабетом, тому що вона дозволяе скоротити час операціï, не потребує абдомінального доступу та значних витрат на синтетичні матеріали. Призначення естрогенвмісних препаратів за 30 діб до оперативного втручання та протягом 30 діб після нього підвищує ефективність хірургічного лікування, нормалізуе гормональний стан та якість життя жінок похилого віку з цукровим діабетом.

\section{ВИСНОВКИ}

1. Наявність цукрового діабету у хворої на генітальний пролапс суттєво впливає на результативність хірургічного лікування, підвищуючи кількість післяопераційних ускладнень.

2. Оптимальним хірургічним втручанням з приводу генітального пролапсу у хворих на цукровий діабет можна вважати однобічну сакроспінальну суспензію, яка дає найменшу кількість рецидивів. Використання поліпропіленової сітки, до складу якої входить поліглікапролактон, можливо у жінок із ЦД, але існує небезпека відторгнення та больового синдрому.

3. Зміни гормонального фону хворих на ГП з ЦД потребують його корекції перед та після операції. Оптимальним можна вважати використання препаратів з естрогенами для місцевого застосування, що покращуе результати хірургічного лікування та якість життя жінок.

\section{ЛITEPATУРA (REFERENCES)}

1. American Diabetes Association. Diabetes Care 2018; 41(1): S13-S27. doi: 10.2337/dc18-S002.

2. Petrov JuA, Kupina AD. Sovremennye problemy nauki i obrazovanija 2020; 2 .

3. Dovgalev RV, Benjuk VA, Nykonjuk TR. Zb. nauk. prac' Asociacii' akusheriv-ginekologiv Ukrai'ny, Kyi'v, 2013:127-131.

4. Leng B, Zhou Y, Du S, et al. Eur J Obstet Gynecol Reprod Biol 2019; 235: 19-25.

5. Lee UJ, Kerkhof MH, Van Leijsen SA, Heesakkers JP. Curr Opin Urol 2017; 27(5): 428-434.

6. Jacentjuk VV. Zdorov'e zhenshhyny 2015; 5: 59-61, available at: http://nbuv.gov.ua/UJRN/Zdzh_2015_5_14.

7. Grygorenko AP, Shymans'ka-Gorbatjuk OG, Shatkovs'ka NS, Garbuzjuk VV. Zb.nauk.prac' Asociacii' akusheriv-ginekologiv Ukrai'ny, Kyi'v, 2013: 93-96.

8. Fleischer K, Thiagamoorthy G. Post Reprod Health 2020; 26(2): 79-85.
9. Abdool Z, Dietz HP, Lindeque BG. Int Urogynecol $J$ 2017; 28(9): 1387-1391.

10. Gromyko NL, et al. Reproductive health. Eastern Europe 2017; 7(3): 437-439.

11. Zhang L, Zheng P, Duan A, et al. Mol Med Rep 2019; 19(1): 391-399.

12. Shkarupa DD, Kubin ND., Popov JeN, et al. Zhurnal akusherstva $i$ zhenskih boleznej 2018; 67(3): 55-63.

13. Caruso S, Cianci S, Vitale SG, et al. Menopause 2017; 24(8): 900-907.

14. Lethaby A, Ayeleke RO, Roberts H. Cochrane Database Syst Rev.2016.

15. Smith BC, Crisp CC, Kleeman SD, et al. Female Pelvic Med Reconstr Surg 2019; 25(2): 93-98.

16. Aleixo GF, Fonseca MCM, Bortolini MAT, et al. Int Urogynecol J 2019; 30(2): 181-190. 


\section{ВПЛИВ ЦУКРОВОГО ДІАБЕТУ НА РЕЗУЛЬТАТИВНІСТЬ ХІРУРГІЧНОГО ЛІКУВАННЯ ГЕНІТАЛЬНОГО ПРОЛАПСУ}

Сафонов Р. А., ${ }^{1,2}$ Лазуренко В. В. ${ }^{1}$, Пасіешвілі Н. М. ${ }^{3}$, Карпенко В. Г. ${ }^{4}$, Садчикова М. В. ${ }^{5}$

${ }^{1}$ Харківський національний медичний університет, м. Харків, Украӥна

${ }_{2}^{2}$ Харківський регіональний перинатальний иентр, м. Харків, Украйна; ${ }^{3}$ Харківський обласний клінічний перинатальний иентр, м. Харків, Україна;

${ }^{4}$ Харківський національний університет іл. В. Н. Каразіна, м. Харків, Украӥна;

${ }^{5}$ Харківська медична академія післядипломної освіти, м. Харків, Україна urology.edu.ua@gmail.com

Мета: оптимізація хірургічного лікування генітального пролапсу (ГП) у жінок з цукровим діабетом (ЦД) та визначення впливу останнього на результативність хірургічного лікування ГП шляхом порівняння різноманітних сучасних підходів до терапії ГП.

Матеріал і методи: Обстежено 52 жінки менопаузального віку з ГП 3-4 ступеня, з них у 30 хворих крім генітального пролапсу діагностували ЦД2 (основна група), у 22 жінки був тільки ГП (група порівняння), контрольну групу склали 20 жінок менопаузального віку без ознак ГП та ЦД. В залежності від методу лікування обстежені жінки були розподілені на три групи. До першої групу включено 18 хворих (9 жінок основної групи та $9-3$ групи порівняння), яким була виконана піхвова екстирпація матки, передня кольпорафія, кольпоперінеорафрія. До другої клінічної групи увійшли 20 хворих (по 10 хворих з основної групи і групи порівняння), яким виконана піхвова екстирпація матки 3 однобічною сакроспінальною фріксаціею купола піхви. У третю групу залучено 14 жінок (по 7 жінок з основної групи і групи порівняння), яким після піхвової екстирпації виконана кольпопексія за допомогою поліпропіленової сітки, до складу якої входить поліглікапролактон.

Результати. В результаті проведеного лікування в основній групі виявилося 7 рецидивів (23,3 \%) протягом 1 року після оперативного втручання, з них після вагінальної пластики - 4 випадки (44,4 \%), після сакроспінальної кольпопексії - 1 (10 \%), після встановлення сітчастого протезу полімеш - 2 (28,6 \%). В групі порівняння відмічалося 5 рецидивів (22,7 \%), з яких 3 (33,3 \%) випадки після вагінальної пластики та по одному після сакроспінальної кольпопексії (10\%) та встановлення поліпропіленової сітки, до складу якої входить поліглікапролактон (14,3%). Таким чином, найбільш часті рецидиви у жінок з ЦД були після вагінальної пластики $(44,4$ \%), але більше, ніж у жінок без ЦД (33,3 \%). Після сакроспінальної кольпопексії частота рецидивів була однаковою (по 10 \%) та найнижчою серед інших методів хірургічного лікування. Застосування поліпропіленової сітки, до складу якої входить поліглікапролактон, призвело до ускладнень у 23,3 \% хворих на ЦД та у $22,7 \%$ - без екстрагенітальної патології. Отримані дані вказують на високу ефрективність сакроспінальної кольпопексії в лікуванні ГП у жінок з ЦД, особливо однобічний оперативний підхід.

Висновки. Наявність цукрового діабету у хворої на генітальний пролапс суттево впливае на результативність хірургічного лікування, підвищуючи кількість післяопераційних ускладнень. Оптимальним хірургічним втручанням з приводу генітального пролапсу у хворих на цукровий діабет можна вважати однобічну сакроспінальну суспензію, яка дає найменшу кількість рецидивів. Використання поліпропіленової сітки, до складу якої входить поліглікапролактон, можливо у жінок з ЦД, але існуе небезпека відторгнення та больового синдрому. Зміни гормонального фрону хворих на ГП з ЦД потребують його корекції перед та після операції, оптимальним можна вважати використання препаратів з естрогенами для місцевого застосування, що покращуе результати хірургічного лікування та якість життя жінок.

К л юч о ві с лов а : генітальний пролапс, цукровий діабет 2 типу, хірургічне лікування, кольпоперінеорафія, кольпопексія, сакропексія. 


\title{
THE IMPACT OF DIABETES MELLITUS ON THE EFFECTIVENESS OF SURGICAL TREATMENT OF GENITAL PROLAPSE
}

\author{
Safonov R. A. ${ }^{1,2}$, Lazurenko V. V. ${ }^{1}$, Pasiyeshvili N. M. ${ }^{3}$, \\ Karpenko V. G. ${ }^{4}$, Sadchikova M. V. ${ }^{5}$ \\ ${ }^{1}$ Kharkiv National Medical University, Kharkiv, Ukraine; \\ ${ }^{2}$ Kharkiv Regional Clinical Hospital, Kharkiv, Ukraine; \\ ${ }^{3}$ Kharkiv Regional Clinical Perinatal Center, Kharkiv, Ukraine, \\ ${ }^{4}$ V. N. Karazin Kharkiv National University, Kharkiv, Ukraine; \\ ${ }^{5}$ Kharkiv Medical academy of postgraduate education, Kharkiv, Ukraine \\ urology.edu.ua@gmail.com
}

The purpose of the study was to optimize the surgical treatment of genital prolapse (GP) in women with diabetes mellitus and to determine its impact on the effectiveness of GP surgical treatment by comparing various modern approaches.

Material and methods. 52 menopausal women with GP of 3-4 degrees were examined. 30 women were diagnosed with type 2 diabetes mellitus (main group) in addition to genital prolapse, 22 women had only GP (comparison group), the control group consisted of 20 menopausal women without signs of GP and type 2 diabetes mellitus. Depending on the method of treatment, the examined women were divided into three groups. The first clinical group included 18 patients (9 women of the main group and 9 patients from the comparison group) who underwent uterus vaginal extirpation, anterior colporrhaphy, colpoperineoraphy. The second clinical group consisted of 20 patients (10 patients from the main group and 10 women from the comparison group) who underwent uterus vaginal extirpation with unilateral sacrospinal fixation of the vagina dome. The third group had 14 women ( 7 patients from the main group and 7 women from the comparison group), who after vaginal extirpation underwent colpopexy using a polypropylene mesh, which includes polyglycaprolactone.

Results. As a result of the treatment there were 7 recurrences $(23.3 \%)$ within 1 year after surgery in the main group. They were 4 cases $(44.4 \%)$ after vaginal plastic surgery, 1 (10 \%) patient after sacrospinal colpopexy, and $2(28.6 \%)$ women after using polypropylene mesh, which included polyglycaprolactone. There were 5 recurrences $(22.7 \%)$ in the comparison group: $3(33.3 \%)$ cases were after vaginal plastic surgery, 1 (10 \%) woman was after sacrospinal colpopexy, and $1(14.3 \%)$ patient was after the establishment of a polypropylene mesh, which included polyglycoprolactone. Thus, the most frequent recurrences in women with type 2 diabetes mellitus were after vaginal plastic surgery (44.4\%), but it was more than in women without diabetes (33.3 \%). After sacrospinal colpopexy, the recurrence rate was the same (10\%) and the lowest among other surgical treatments. The use of polypropylene mesh, which included polyglycoprolactone, led to complications in $23.3 \%$ of patients with type 2 diabetes mellitus and in $22.7 \%$ of women without extragenital pathology. The obtained data indicate the high efficiency of sacrospinal colpopexy in GP treatment of women with type 2 diabetes mellitus, especially one-sided surgical approach.

Conclusions. Type 2 diabetes mellitus significantly affects the effectiveness of surgical treatment of patients with genital prolapse, increasing the number of postoperative complications. The optimal surgery for genital prolapses in patients with diabetes can be considered a unilateral sacrospinal suspension, which gives the lowest number of recurrences. The use of polypropylene mesh, which includes polyglycaprolactone, is possible in women with type 2 diabetes mellitus, but there is a high probability of rejection and pain. Changes in the endocrine profile of patients with GP and type 2 diabetes mellitus require its correction both in pre- and postoperative periods. The local use of estrogen drugs can be considered optimal for improving the results of surgical treatment and the quality of life of women.

Key words: genital prolapse, type 2 diabetes mellitus, surgical treatment, colpoperineoraphy, colpopexy, sacropexy. 